Indexed by

\title{
Scopus
}

\section{PARAMETRIC STUDY OF A SOLAR DRYER SYSTEM FOR THE DEVELOPMENT AND APPLICATION OF SOLAR ENERGY IN SIERRA LEONE}

\section{Abu Bakarr Momodu Bangura}

Department of Engineering Physics, Institut Teknologi Sepuluh Nopember, Surabaya 60111, Indonesia
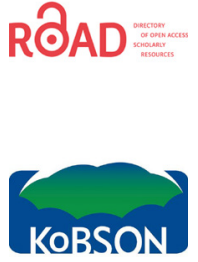

Pierre Damien Uwitije

Engineering, University of Rwanda

\section{Ridho Hantoro}

Department of Engineering

Physics, Institut Teknologi

Sepuluh Nopember, Surabaya

60111, Indonesia

\author{
Ahmad Fudholi \\ Solar Energy Research \\ Institute, Universiti \\ Kebangsaan Malaysia, \\ 43600 Bangi Selangor, \\ Malaysia \\ Research Centre for \\ Electrical Power and \\ Mechatronics, Indonesia \\ Institute of Sciences (LIPI), \\ Bandung, Indonesia
}

Key words: double-pass collector, drying chamber, mathematical model, onion, solar energy in Sierra Leone, thermal efficiency doi:10.5937/jaes0-33614

Cite article:

Bakarr Momodu Bangura A., Hantoro R., Fudholi F., Damien Uwitije P. (2022) PARAMETRIC STUDY OF A SOLAR DRYER SYSTEM FOR THE DEVELOPMENT AND APPLICATION OF SOLAR ENERGY IN SIERRA LEONE, Journal of Applied Engineering Science, 20(2), 408 - 419 , DOI:10.5937/ jaes0-33614

Online aceess of full paper is available at: www.engineeringscience.rs/browse-issues 


\title{
PARAMETRIC STUDY OF A SOLAR DRYER SYSTEM FOR THE DEVELOPMENT AND APPLICATION OF SOLAR ENERGY IN SIERRA LEONE
}

\author{
Abu Bakarr Momodu Bangura1*, Ridho Hantoro', Ahmad Fudholi, ${ }^{2,3}$, Pierre Damien Uwitije ${ }^{4}$ \\ ${ }^{1}$ Department of Engineering Physics, Institut Teknologi Sepuluh Nopember, Surabaya 60111, Indonesia \\ ${ }^{2}$ Solar Energy Research Institute, Universiti Kebangsaan Malaysia, 43600 Bangi Selangor, Malaysia \\ ${ }^{3}$ Research Centre for Electrical Power and Mechatronics, Indonesia Institute of Sciences (LIPI), \\ Bandung, Indonesia \\ ${ }^{4}$ Mechanical \& Energy Engineering, University of Rwanda
}

A transient mathematical model has been evaluated to determine the principle of a solar crop dryer for drying vegetables (onion). Considering the meteorological conditions of Freetown (Latitude $8.484^{\circ} \mathrm{N}$, Longitude $-13.230^{\circ} \mathrm{W}$ ), the model was developed to determine air temperatures and other operational parameters of the drying system for a day of March 21st. However, the investigated system had effectively reduced the drying process of onion. The developed double-pass solar air collector system showed a low-temperature output in the morning hours and displayed high-temperature results in the afternoon hours. From 8:00 to 16:00, the solar collector generates fluid output temperatures above $50^{\circ} \mathrm{C}$, with a peak value of $96^{\circ} \mathrm{C}$ occurred at 12:00. The influence of the mass flow rate on the system's thermal efficiency was investigated. It was noticed that for a certain solar radiation value, an increased in the mass flow rate caused an exponential increased in the solar air collector thermal efficiency. Findings also revealed that an increased in the solar collector length led to a slightly decreased in the outlet air temperatures at a mass flow rate of $0.02 \mathrm{~kg} / \mathrm{s}$. The influence of increasing drying air temperatures and air velocity within the drying chamber reduces drying time significantly. The drying time for products dried in the first tray is lesser than for products dried in the subsequent trays, owing to temperature variations. The computation findings were verified to previous studies in the literature and observed to be strongly comparable.

Key words: double-pass collector, drying chamber, mathematical model, onion, solar energy in Sierra Leone, thermal efficiency

\section{INTRODUCTION}

Fruits and vegetables remain extremely frequent, with significant quantities produced at specific times of the year [1]. During peak periods, market rates are generally at their lowest, resulting in reduced income and sometimes profits for the producer. The surplus could also result in the deterioration of significant quantities due to abundant production during the harvest. Preserving these fruits and vegetables will help minimize food waste and make foods more accessible during the off-season [2]. Moisture levels are very high in a wide variety of food products. Consequently, if not stored in mechanically managed equipment, it will have a high potential for significant quality degradation, perhaps to the point of bacteria growth [3]. Drying is the oldest method of preserving agricultural products. However, it is a time-consuming and energy-intensive operation. Solar drying has long been thought to be the most extensively employed solar energy technique for food preservation. Solar dryers are favoured since they are simple to construct with locally accessible tools and materials. One of the most energy-intensive activities in the food sector is drying fruits and vegetables [4]. Due to rising global oil prices and scarcity, a greater focus is placed on environmentally friendly renewable energy systems [5]. In many tropical and subtropical regions, sun drying is being commonly practiced. The inexpensive approach is sun drying; however, the dried products' consistency falls well short of global standards. On the other hand, this operation has quite a range of drawbacks, including product spoilage due to weather conditions, wind, precipitation, debris, production loss due to birds and animals, crop degradation due to decay, insect infestation, and fungi [3]. Effective drying techniques are the only method of improving product quality and minimizing economic loss [6]. Vaporizing water in the substance is typically used to dry it. As a result, vaporization latent heat should be given. The moisture must be extracted from the product, which necessitates air circulation. Because less humid air absorbs more moisture away from the product surface than more humid air, the greater the drying rate, the lower the temperature of the heated air delivered to the drying chamber [7]. The drying time is typically reduced by increasing the air temperature and velocity [8]. High temperature on the other hand, degrade the consistency of heat-sensitive items like food and pharmaceuticals. In this case, using the desiccant method, low-temperature and high-humidity drying is needed to preserve the product's fresh color $[8,9]$. Without using a desiccant system, low humidity can be achieved. A high 
temperature is needed. A wide range of complications associated with the use of desiccant substance in dehydration processes have been thoroughly examined by [11]. Different drying methods yields different levels of product quality within the same material [12]. Solar drying is a more sophisticated form of sun drying and is a cost-effective way to utilize solar energy $[12,13]$. Given the current state of food insecurity worldwide, cost-effective and sanitary food preservation methods are critical. Compared to conventional drying methods such as sun or shade drying, the introduction of drying systems in developing and underdeveloped countries can substantially reduce post-harvest losses and enhance food quality [15]. In light of the global population annual growth, food production and preservation play a vital role in reducing hunger, specifically in developing countries. Modernization, cultivation, and food waste control are critical measures for maintaining sufficient food access to meet current and potential demand. Implementation of preservation methods that maximize nutritional value, expense, and energy demand is needed to reduce the food deficit. Mechanical, thermal dryers uses a massive amount of energy, have quite a high initial and operating cost, and cause a negative impact on global warming [16]. However, in some developing countries like Sierra Leone, cool ambient air prolongs some agricultural products drying process. Consequently, certain products that requires a high amount of energy for drying possess serious challenges. The huge losses arising from these consequences can be significant, especially for fruits and vegetables, which deteriorates rapidly if not preserved. The use of solar dryers in an enclosed heat transfer process has become a much more optimal and cost-effective choice as a result of the refinement of traditional open sun drying, particularly in remote areas with no electricity access [17]. Undoubtedly, in the analysis of drying system efficiency, it is essential to implement new concepts that are both effective and feasible. The advancement of modeling techniques and simulation software has been extremely beneficial in analyzing results, enhancing the efficiency of the process, forecasting temperature changes, moisture levels, and drying time for various products [18]. Numerous analyses have been investigated the modeling of solar drying of agricultural commodities as well as numerical simulations of solar dryers (direct and indirect) and the drying characteristics of diverse veggies and fruits [4]. As a result, for dryer design and operation, simulation models are required. Simulators for natural and forced convection drying systems have been developed by several researchers $[18,19]$. Detailed experimental and computational investigations for several solar dryers operating in various communities have been performed to understand better their efficiency and drying technique for multiple products in distinct locations [21]. Solar drying is only possible during daylight hours. Mostly with solar air heater, a thermal reserve might be created for continual drying [22]. An energy backup component coupled with the solar collector can be charged throughout optimal sunlight hours and used (released) for delivering hot air to the dryer during off hours, and unfavourable weather conditions [23,24]. In the past decades, various solar air collector and crop drier systems have been investigated [25]. Among the widely used solar air collectors are; flat plate single and double-pass, and V-corrugated single and double-pass collectors. The absorber plate might have air flowing above, beneath, or on opposite surfaces. Heat dissipation through the glazing is reduced by air flowing underneath the absorber plate. Since the front surface must be subjected to the ambient, the top cover suffers the most losses from the collector [26]. The solar collector's performance is determined by its kind and design, and also the amount of heat dissipation while in operation [27]. Mathematical analysis and computer programs are useful techniques for establishing energy-efficient design and projecting total drying system efficiency $[28,23]$. In the present study, the main concern is to study the performance of a solar dryer system for onion drying by employing a double-pass solar air collector to implement a new idea of solar air heating. The functioning of the dryer and the different heat transfer coefficients are governed by series of equations. A mathematical simulation enabled us to obtain graphically displayed results, which are then analyzed and discussed.

\section{MATERIALS AND METHODS}

\section{Designed the studied system}

In this study, a typical indirect convectional dryer designed for agricultural products, mostly fruits and vegetables, was used. Fig. 1(a) depicts essentially a simple solar dryer diagram, which has numerous advantages: low space usage and ease of maintenance. However, it comprises of two main components: a double-pass (counter flow) convectional solar air heater, a drying chamber with a fan built on the top. The first principal component of the drying chamber is a double-pass (counter flow) solar air collector tilted at an angle of 150 with respect to the horizontal, as shown in Fig. 2 (a). Its top is made up of a glass cover of $1 \mathrm{~cm}$ thick. A $0.1 \mathrm{~cm}$ thick stainless aluminium plate coated with black acts as a heat exchanger in the center, and a $4 \mathrm{~cm}$ thick back plate insulator serves as the bottom. The air flows in the first and second streams of the absorber plate by convection. Fig. 1(b) shows the internal diagram of the drying chamber. The drying chamber is made up of a 4 $\mathrm{cm}$ thick polystyrene insulator and a $10 \mathrm{~cm}$ thick brick wall that houses 5 wired mesh racks with a $10 \mathrm{~cm}$ gap, wide enough to allow for the most efficient air circulation between each mesh on which the products are laid. The entire drying chamber is a cubic-shaped box with sidewalls that are $100 \mathrm{~cm}$ high. As shown in Fig. 1(b), the fan at the top of the drying chamber is used as an extractor to facilitate forced convection. Mostly, in the event of inclement weather a porous media is placed in the dryer. In most cases a porous media is only utilized once the solar air collector outlet temperature is below $50{ }^{\circ} \mathrm{C}$. 


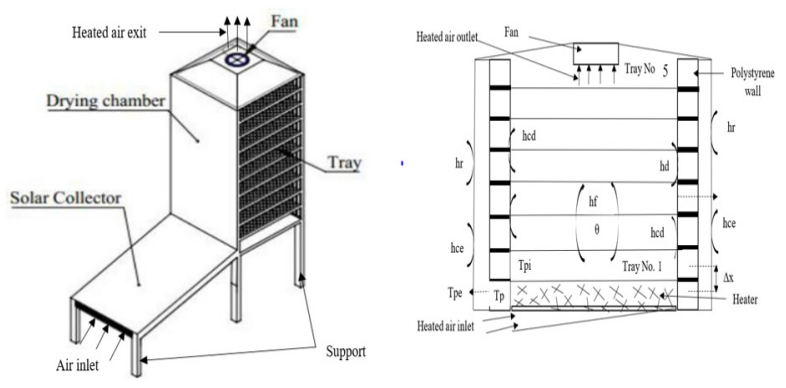

Figure 1: (a) The schematic of a simple solar dryer system, (b) The schematic of the internal view of the solar dryer

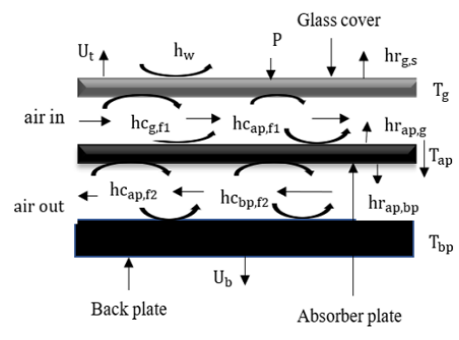

(a)

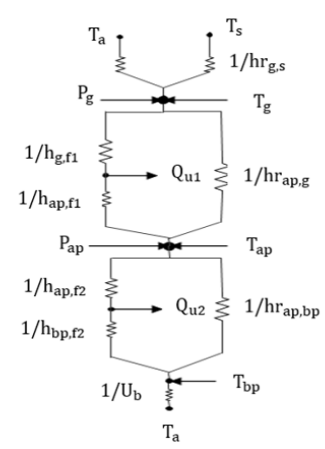

(b)
Figure 2: (a) The schematic of double-pass (counter flow) solar air heater, (b) The schematic of thermal network for double-pass solar air heater

\section{Thermal analysis of the double-pass solar air heater}

In a small collector, the temperature of the airflow influencing borders is consistent. The airflow temperature fluctuates progressively from the collector, corresponding to the theoretical model. In the first section, the wall and average air temperatures are estimated and described. The heat exchange variables are calculated using the temperature values that were assumed at the start. By inverting the function matrix, Excel can calculate the average temperature vector [29].

$[\mathrm{T}]=[\mathrm{Y}]^{-1}[\mathrm{Z}]$

Furthermore, the theoretical model implies that for a small solar air heater, the temperatures of the wall influencing air circulation are consistent (smaller of $10 \mathrm{~m}$ ). As a result, the air stream and collector temperatures vary equally. For the short collectors, the average air temperature will be the same as the arithmetic average as stated by [30]:

$$
\begin{aligned}
& \mathrm{T}_{\mathrm{f} 1}=\left(\mathrm{T}_{\mathrm{f} 1, \mathrm{o}}+\mathrm{T}_{\mathrm{i}}\right) / 2 \\
& \mathrm{~T}_{\mathrm{f} 2}=\left(\mathrm{T}_{\mathrm{f} 2, \mathrm{o}}+\mathrm{T}_{\mathrm{f} 1,0}\right) / 2
\end{aligned}
$$

The following are the key concept parameters: $\mathrm{L}=240 \mathrm{~cm}, \mathrm{~W}_{\mathrm{c}}=120 \mathrm{~cm}, \mathrm{U}_{\mathrm{b}}=1 \mathrm{~W} / \mathrm{m}^{2}{ }^{\circ} \mathrm{C}, \mathrm{k}_{\mathrm{ap}}=211 \mathrm{~W} /$ $\mathrm{m}^{2}{ }^{\circ} \mathrm{C}, \mathrm{T}_{\mathrm{a}}=\mathrm{T}_{\mathrm{i}}=23{ }^{\circ} \mathrm{C}$ and $\mathrm{V}=1 \mathrm{~m} / \mathrm{s}$ [29]. Mostly, the initial conditions for a double-pass (counter flow) solar air heater are; for the first air flow stream, at $x=0, T_{f 1, i}=T_{a}$ , for the second air flow stream, at $x=L, T_{f 2, i}=T_{f 1,0}$. The thermal efficiency of the solar air collector is determined by $[30,31]$.

$\eta=\frac{\dot{\mathrm{m} C}\left(\mathrm{~T}_{\mathrm{o}}-\mathrm{T}_{\mathrm{i}}\right)}{\mathrm{A}_{\mathrm{c}} \mathrm{I}}$

where is the mass flow rate of the fluid, $C$ is the specific heat of the fluid, $T_{0}$ is the outlet air temperature from the solar collector, $T_{i}$ is the inlet air temperature, $A_{c}$ is the cross-sectional area of the solar collector, and $I$ is the solar radiation intensity. The steady-state energy balance in the counter flow segment is investigated using the thermal network depicted in Fig. 2(c). The following are the steady-state heat transfer equations for the double-pass solar air collector components that are considered as a node in the thermal network:

Exchange on the surface of the glass cover:

$\mathrm{P}_{\mathrm{g}}+\mathrm{hr}_{\mathrm{ap}, \mathrm{g}}\left(\mathrm{T}_{\mathrm{ap}}-\mathrm{T}_{\mathrm{g}}\right)+\mathrm{hc}_{\mathrm{g}, \mathrm{f} 1}\left(\mathrm{~T}_{\mathrm{f} 1}-\mathrm{T}_{\mathrm{g}}\right)=\mathrm{U}_{\mathrm{t}}\left(\mathrm{T}_{\mathrm{g}}-\mathrm{T}_{\mathrm{a}}\right)$

Exchange on the first airflow stream:

$h c_{a p, f 1}\left(T_{a p}-T_{f 1}\right)=Q_{u 1}+h c_{g, f 1}\left(T_{f 1}-T_{g}\right)$

The exchange at the absorber plate surface:

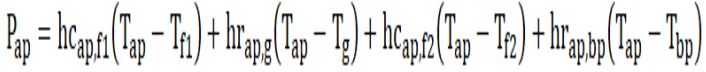

Exchange on the second airflow stream:

$h c_{a p, f 2}\left(T_{a p}-T_{f 2}\right)=h c_{f 2, b p}\left(T_{f 2}-T_{b p}\right)+Q_{u 2}$

And lastly, exchange at the backplate surface:

$\mathrm{hr}_{\mathrm{ap}, \mathrm{bp}}\left(\mathrm{T}_{\mathrm{ap}}-\mathrm{T}_{\mathrm{bp}}\right)+\mathrm{hc}_{\mathrm{f} 2, \mathrm{bp}}\left(\mathrm{T}_{\mathrm{f} 2}-\mathrm{T}_{\mathrm{bp}}\right)=\mathrm{U}_{\mathrm{b}}\left(\mathrm{T}_{\mathrm{bp}}-\mathrm{T}_{\mathrm{a}}\right)$

with;

$Q_{\mathrm{u} 1}=2 \dot{\mathrm{m} C}\left(\mathrm{~T}_{\mathrm{f} 1}-\mathrm{T}_{\mathrm{f} 1, \mathrm{i}}\right) / \mathrm{WL}$

$\mathrm{Q}_{\mathrm{u} 2}=2 \dot{\mathrm{m} C}\left(\mathrm{~T}_{\mathrm{f} 2}-\mathrm{T}_{\mathrm{f} 2, \mathrm{i}}\right) / \mathrm{WL}$

Eqs. (5-9) defines the heat transfer coefficients (HTCs) of the double-pass solar collector. Considering the above relationship in Eqs (6) and (8), and performing certain mathematical readjustments, the average temperature variable can be computed by Excel employing the matrix inversion form of Eq (1). The iterative approach used necessitates pre-existing understanding of the surrounding conditions $\left(T_{a}, h_{w}, I\right)$, temperature of the air inlet $\left(T_{i}\right)$, absorber plate and glass refractive and radiative pa- 
rameters $\left(a_{p}, \varepsilon_{a p}, \alpha_{g}, \varepsilon_{g}, T_{g}\right)$, thermophysical characteristics of air at a specific average temperature $(k, \rho, C, \mu)$, as well as stream geometry $\left(D_{h}, L, W_{c}\right)$. Furthermore, the first air flow stream average temperatures $\left(T_{f 1}\right)$, the second air flow stream $\left(T_{f 2}\right)$, glass $\left(T_{g}\right)$, absorber plate $\left(T_{a p}\right)$ , and back $\left(T_{b p}\right)$ plate insulator are specified for the first segment, which are initially assumed. All of the needed HTCs are computed in Excel. HTCs are evaluated based on the temperature parameters that were previously estimated. In addition, the matrices $[\mathrm{X}],[\mathrm{Y}]$ and $[\mathrm{Z}]$ are then established. After that, a standard matrix inversion function is executed to invert the matrix [Y] to come up with a new set of temperature matrix $\left[\mathrm{T}^{\prime}\right]$. In the matrix, a new temperature value [ $\left.\mathrm{T}^{\prime}\right]$ is then verified with the equivalent initially assumed value [ $\left.\mathrm{T}^{\prime}\right]$. The iteration is ended if the divergence between any corresponding new and old values reaches $0.01{ }^{\circ} \mathrm{C}$, and thus, the previous temperatures are substituted with the recently computed ones and used as the appropriate temperatures at the section of interest. Usually, $T_{g}, T_{f 1}, T_{a p}, T_{f 2}$ and $T_{b p}$ convergence is obtained in at most six iterations. The second stream input air temperature is set to the same as the first stream exit air temperature. Upon obtaining the exit air temperatures from the second stream of the collector, various parameters of the solar collector are computed, as well as the thermal efficiency of the collector using Eq (4) $[29,32]$. The physical characteristics of air are presumed to progressively vary with temperature $\left({ }^{\circ} \mathrm{C}\right)$ by Ong [32]:

Specific heat of air

$\mathrm{Cp}=1.0057+0.000066(\mathrm{~T}-27)$

Density of air

$\rho_{\text {air }}=1.1774-0.00359(\mathrm{~T}-27)$

Thermal conductivity

$\mathrm{k}=0.02624+0.0000758(\mathrm{~T}-27)$

Viscosity of air

$\mu_{\text {air }}=[1.983+0.00184(\mathrm{~T}-27)] 10^{-5}$

\section{Estimation of Heat Transfer Coefficients}

The heat transfer coefficients for the various modes are determined accordingly, such as $[31,32]$. Heat transfer coefficient due to wind by convection:

$\mathrm{h}_{\mathrm{w}}=2.8+3.3 \mathrm{~V}$

Exchange across glass surface and sky by radiation:

$\mathrm{hr}_{\mathrm{g}, \mathrm{s}}=\frac{\sigma \varepsilon_{\mathrm{g}}\left(\mathrm{T}_{\mathrm{g}}+\mathrm{T}_{\mathrm{s}}\right)\left(\mathrm{T}_{\mathrm{g}}^{2}+\mathrm{T}_{\mathrm{s}}^{2}\right)\left(\mathrm{T}_{\mathrm{g}}-\mathrm{T}_{\mathrm{s}}\right)}{\left(\mathrm{T}_{\mathrm{g}}-\mathrm{T}_{\mathrm{a}}\right)}$ with:

$\mathrm{T}_{\mathrm{s}}=0.0552 . \mathrm{T}_{\mathrm{a}}^{1.5}$

Exchange across the glass cover and absorber plate by radiation:

$\mathrm{hr}_{\mathrm{ap}, \mathrm{g}}=\frac{\sigma \varepsilon_{\mathrm{ap}} \varepsilon_{\mathrm{g}}\left(\mathrm{T}_{\mathrm{ap}}+\mathrm{T}_{\mathrm{g}}\right)\left(\mathrm{T}_{\mathrm{ap}}^{2}+\mathrm{T}_{\mathrm{g}}^{2}\right)}{\varepsilon_{\mathrm{ap}}+\varepsilon_{\mathrm{g}}-\varepsilon_{\mathrm{ap}} \varepsilon_{\mathrm{g}}}$

Exchange across the absorber plate and backplate by radiation:

$\mathrm{hr}_{\mathrm{ap}, \mathrm{bp}}=\frac{\sigma \varepsilon_{\mathrm{ap}} \varepsilon_{\mathrm{bp}}\left(\mathrm{T}_{\mathrm{ap}}+\mathrm{T}_{\mathrm{bp}}\right)\left(\mathrm{T}_{\mathrm{ap}}^{2}+\mathrm{T}_{\mathrm{bp}}^{2}\right)}{\varepsilon_{\mathrm{ap}}+\varepsilon_{\mathrm{bp}}-\varepsilon_{\mathrm{ap}} \varepsilon_{\mathrm{bp}}}$

Exchange across the absorber plate and backplate by radiation:

$\mathrm{hr}_{\mathrm{ap}, \mathrm{bp}}=\frac{\sigma \varepsilon_{\mathrm{ap}} \varepsilon_{\mathrm{bp}}\left(\mathrm{T}_{\mathrm{ap}}+\mathrm{T}_{\mathrm{bp}}\right)\left(\mathrm{T}_{\mathrm{ap}}^{2}+\mathrm{T}_{\mathrm{bp}}^{2}\right)}{\varepsilon_{\mathrm{ap}}+\varepsilon_{\mathrm{bp}}-\varepsilon_{\mathrm{ap}} \varepsilon_{\mathrm{bp}}}$

The following equations are used to compute the convective heat transfer coefficients [30].

$\mathrm{hc}=\frac{\mathrm{k}}{\mathrm{D}_{\mathrm{h}}} \mathrm{Nu}$

where $\mathrm{Nu}$ is the Nusselt number, and $D_{h}$ is the equivalence diameter of the stream. Nusselt number for laminar flow zone for $(\operatorname{Re}<2300)$ [32,33].

$\mathrm{Nu}=5.4+\frac{0.00190\left[\operatorname{RePr}\left(\frac{\mathrm{D}_{\mathrm{h}}}{\mathrm{ep}}\right)\right]^{1.71}}{1+0.00563\left[\operatorname{RePr}\left(\frac{\mathrm{D}_{\mathrm{h}}}{\mathrm{ep}}\right)\right]^{1.17}}$

For transition flow region $(2300<\mathrm{Re}<6000)$ :

$\mathrm{Nu}=0.116\left(\operatorname{Re}^{2 / 3}-125\right) \operatorname{Pr}^{1 / 3}\left[1+\left(\frac{D_{\mathrm{h}}}{\text { ep }}\right)^{2 / 3}\right]\left(\frac{\mu}{\mu_{\text {eep }}}\right)^{0.14}$

Turbulence flow region $(\operatorname{Re}>6000)$

$\mathrm{Nu}=0.018 \mathrm{Re}^{0.8} \operatorname{Pr}^{0.4}$

where Pr is the Prandtl number, and Re is the Reynolds number

$\mathrm{Re}=\frac{\dot{\mathrm{m}} \mathrm{D}_{\mathrm{h}}}{\mathrm{A}_{\mathrm{c}} \mu}$

$D_{h}=\frac{4 \cdot W_{c} \cdot d}{2\left(W_{c}+d\right)}$ 
Where $D_{h}$ is equivalence diameter, $d$ is stream depth and $W_{c}$ is the width of the collector.

\section{Theoretical approach of the drying chamber}

The step-by-step mathematical model has been used to model the drying chamber. In contrast to previous approaches, like Hottel et al. global techniques, the step by step approach provides for the development of temperatures of all solar dryer components in time and space, as well as the impacts of temperature variations [34]. This drying chamber is considered to be partitioned into a series of imaginary segments separated by two shelves and the chamber's boundaries in the path of airflow. Considering the heat and energy equilibrium for each component in Fig. 1(b), the equations regulating thermal and mass transfers at the segment level are formulated as follows: Exchange at the polystyrene wall external surface:

$\frac{m p_{p} C p_{p}}{4}\left(\frac{d T_{p e}}{d t}\right)=k_{p}, S_{v}\left(T_{p}-T_{p e}\right)+h_{a m p e}\left(T_{a m}-T_{p e}\right)+h_{1} S_{v}\left(T_{c}-T_{p e}\right)$

Exchange through the brick wall and the polystyrene wall faces:

$\frac{m p_{p} C p_{p}}{4}\left(\frac{d T_{p}}{d t}\right)+k_{p}, S_{V}\left(T_{p}-T_{p e}\right)=\frac{m p_{b} C p_{b}}{4}\left(\frac{d T_{p}}{d t}\right)+k_{b}, S_{V}\left(T_{p}-T_{p i}\right)$

Exchange at the internal brick wall surface:

$\frac{\mathrm{mp}_{\mathrm{b}} \mathrm{C} \mathrm{p}_{\mathrm{b}}}{4}\left(\frac{\mathrm{dT} \mathrm{pi}}{\mathrm{dt}}\right)=\mathrm{k}_{\mathrm{b}} \cdot \mathrm{S}_{\mathrm{v}}\left(\mathrm{T}_{\mathrm{p}}-\mathrm{T}_{\mathrm{pi}}\right)+\mathrm{h}_{\mathrm{ach}, \mathrm{pi}} \cdot \mathrm{S}_{\mathrm{v}}\left(\mathrm{T}_{\mathrm{ach}}-\mathrm{T}_{\mathrm{pi}}\right)$

Exchange through the product, internal wall surface and the drying air At the internal surface of the brick wall:

$\dot{\mathrm{m}}_{\text {ach }} \mathrm{C}_{\text {air }}\left(\mathrm{T}_{\mathrm{ach}}^{*}-\mathrm{T}_{\text {ach }}\right)=\mathrm{h}_{\text {ach,f }} \mathrm{S}_{\mathrm{f}}\left(\mathrm{T}_{\mathrm{ach}}-\mathrm{T}_{\mathrm{f}}\right)+4 \cdot \mathrm{h}_{\text {ach pi }} \mathrm{S}_{\mathrm{V}}\left(\mathrm{T}_{\mathrm{ach}}-\mathrm{T}_{\mathrm{pi}}\right)$

Exchange between the product and the drying air:

$\mathrm{m}_{\mathrm{f}} \mathrm{Cp}_{\mathrm{f}}\left(\frac{\mathrm{dT}_{\mathrm{f}}}{\mathrm{dt}}\right)=\mathrm{h}_{\mathrm{ach}, \mathrm{f}} \cdot \mathrm{S}_{\mathrm{f}}\left(\mathrm{T}_{\mathrm{ach}}-\mathrm{T}_{\mathrm{pi}}\right)-\mathrm{P}_{\mathrm{ev}}$

* Depicts the precedent tray

Where the vaporization power is expressed as:

$\mathrm{P}_{\mathrm{eva}}=\frac{\mathrm{dX}}{\mathrm{dt}} \cdot \mathrm{m}_{\mathrm{sec}} \cdot \mathrm{L}_{\mathrm{vap}}$

with $\mathrm{m}_{\mathrm{sec}}$ is the mass $(\mathrm{kg})$ of the dried product, $\mathrm{L}_{\mathrm{vap}}$ is the latent heat of vaporization $(\mathrm{J} / \mathrm{kg})$, and $\mathrm{dX} / \mathrm{dt}$ is the moisture content variation with time $(\mathrm{kg} / \mathrm{kg}$ d.b.s)

The exchange surface is expressed as:
$\mathrm{S}_{\mathrm{f}}=\pi \mathrm{D}^{2} \mathrm{n}$

with $\mathrm{n}$ being the quantity of dried item packed per tray.

The fluctuation of moisture content is computed by employing the following formula [35].

$K\left(X-X_{e}\right) m_{s e c}=\left(W_{a c h, o}-W_{a c h}\right) \dot{m}_{a c h}$

The fluctuation of $X$, that indicates the product's moisture level throughout the drying process is required. As a result, a better understanding of drying kinetics is essential

\section{Drying kinetics}

The first order empirical approach was used to simulate the activity of moisture absorption inside the onion. It is expressed as [34,36]:

$-\frac{\mathrm{dX}_{\mathrm{s}}}{\mathrm{dt}}=\mathrm{K}_{\mathrm{c}}\left(\mathrm{X}_{\mathrm{s}}-\mathrm{X}_{\mathrm{se}}\right)$

Where $X_{s}$ denotes the moisture content of the product (dry basis) during drying ( $\mathrm{kg}$ water/kg dry solids), $X_{\mathrm{se}}$ is the equilibrium moisture content of the dehydrated product and is the drying time (min). The dehydration parameter $\mathrm{K}_{\mathrm{C}}$ ensures the gradient of the falling rate as a result of the drying curve defined by [34].

$K_{c}=K_{0} D^{K D} T_{a c h}^{K T} W_{a c h}^{K W} U_{a c h}^{K U}$

where $\mathrm{K}_{0}$ is a constant $\left(\mathrm{h}^{-1}\right.$ or $\left.\mathrm{min}^{-1}\right), \mathrm{KD}, \mathrm{KT}, \mathrm{KW}$ and $\mathrm{KU}$, are theoretical dimensionless parameters that vary depending on the materia, $\mathrm{D}$ is the particle diameter $(\mathrm{m})$, $\mathrm{T}_{\text {ach }}$ is the dry buld temperature of air $\left({ }^{\circ} \mathrm{C}\right), \mathrm{W}_{\text {ach }}$ is relative humidity of the air (\%), and $U_{\text {ach }}$ is the air velocity $(\mathrm{m} / \mathrm{s})$ [37]. Numerous mathematical equations containing several variables can be used to characterize the equilibrium moisture content of substances. The model becomes extremely complicated as the number of variables increases, making it more difficult to interpret and apply. Kiranoudis [38] reported that the GAB equation variables for onion and other vegetables are estimated, including physical properties such as:

$\mathrm{X}_{\mathrm{se}}=\frac{\mathrm{X}_{\mathrm{m}} \mathrm{Cka}_{\mathrm{w}}}{\left(1-\mathrm{ka}_{\mathrm{w}}\right)\left(1-(1-\mathrm{C}) \mathrm{ka}_{\mathrm{w}}\right)}$

where the material equilibrium moisture content is $X_{\text {se' }}$, the water activity is $a_{w}$, the monolayer moisture content is $X_{m}, C$, and $k$ are associated to the effect of temperature. The onion is assumed in this study as a sphere object, and its composition is: $87.60 \%$ water content, 1.25 $\%$ protein content, $4.91 \%$ carbohydrate content, $0.25 \%$ fat content, and $5.99 \%$ other contents.

The onion's specific heat may be determined by [39]:

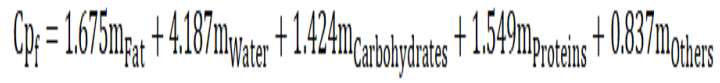


The physical properties of the dryer are updated for each time step and each batch, allowing shrinkage impacts to be considered $[39,40]$. The hot air velocity $U_{\text {ach }}$ surrounding the item can be calculated as:

$U_{\text {ach }}=U / P_{o}$

where $U$ is the velocity of air within the drying chamber, and $P_{0}$ is the porosity rate. Its equivalent is given as:

$\mathrm{P}_{\mathrm{o}}=1-\mathrm{Oc}$

where $\mathrm{Oc}$ is the occupation rate and it is given as:

$\mathrm{Oc}=\mathrm{n} \frac{\pi \mathrm{D}_{\mathrm{f}}^{3}}{6} \frac{1}{\text { long. larg. } \mathrm{D}_{\mathrm{f}}}$

where $D_{f}$ is the product diameter, long, and larg are the length and width of the drying chamber respectively.

\section{Drying Chamber Numerical Approach}

An approximate differential equations approach is adopted and employed to characterize each equation in time and space in order to resolve analytically the set of five generated equations [Eqs (42-46)] for the drying chamber. Following that, each pair of derived equation is resolved into a matrix system of the form $[Q][T]=[R]$, wherein, the vector $[T]$ indicates the vector of the five undetermined parameters. Next, a Matlab code was generated for the drying chamber wherein the Gauss-Seidel iterative technique was employed to solve the system of equations [40]. Once the requisite accuracy is achieved, the computations are declared successful. Else, the computed parameters are assumed to be incorrect and the computation is repeated to the acceptable accuracy.

\section{Input Parameters}

The model has been analyzed mathematically for Freetown (Latitude $8.484^{\circ} \mathrm{N}$, Longitude $-13.230^{\circ} \mathrm{W}$ and altitude $26 \mathrm{~m}$ from mean sea level) clamatic weathr conditions during March (day of year, $n=80$ ). Numerous formulation involving in predicting prominent solar angles are used to determine the overall input data employing the ASHRAE model for sunny weather [41]. In addition, this ASHRAE mathematical model is based on meteorological parameters for Freetown on March $21^{\text {st }}$. March $21^{\text {st }}$ was choosen in accondacnce with the ASHRAE model. Based on the meteorological weather condistions of Freetown, March is the most clearest/ cloudless month among the other months of the year. March is also the harvest season of onions in Freetown. The sinusoidal technique is analyzed to measure the ambient temperature data [41] since Sierra Leone has a mild weather with optimal temperatures ranging from $23{ }^{\circ} \mathrm{C}$ to $30{ }^{\circ} \mathrm{C}$ in March. Hourly average solar radiation intensity and ambient air temperature employed to solve the model are displayed in Fig. 3. The peak radiation intensity captured by the glass cover and absorber plate is obtained by calculating the direct, diffused, and reflected components displayed in Fig. 3. As a result, the peak solar radiation intensity occurs at 12:00. The peak ambient temperature occurs at 14:00, lags two hours following the maximum solar radiation intensity.

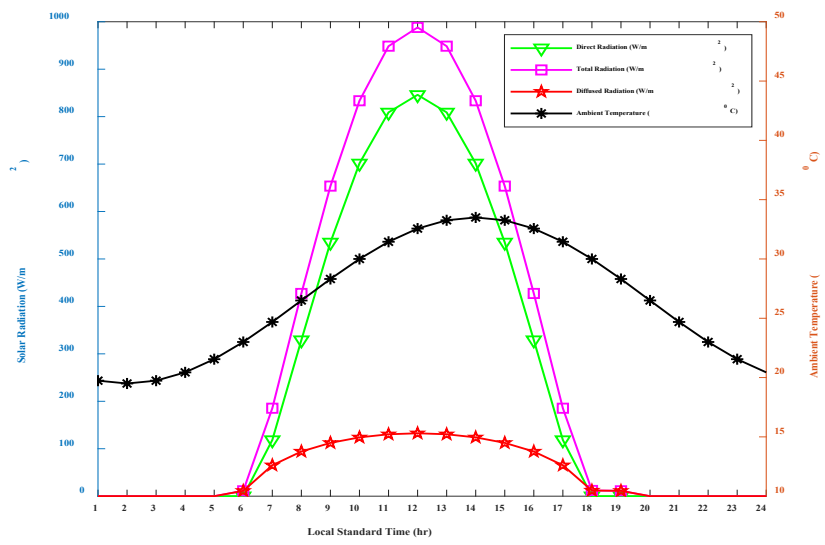

Figure 3: Diurnal variation of average solar radiation and ambient temperature during March 21st

\section{RESULTS AND DISCUSSION}

\section{Performance of the double-pass solar air collector}

A computer program was developed to compute the energy balance equations (5-9) on the double-pass solar air collector to determine the temperatures of the air in the first stream $\left(T_{f 1}\right)$, second stream $\left(T_{f 2}\right)$, and absorber plate $\left(\mathrm{T}_{\mathrm{ap}}\right)$.

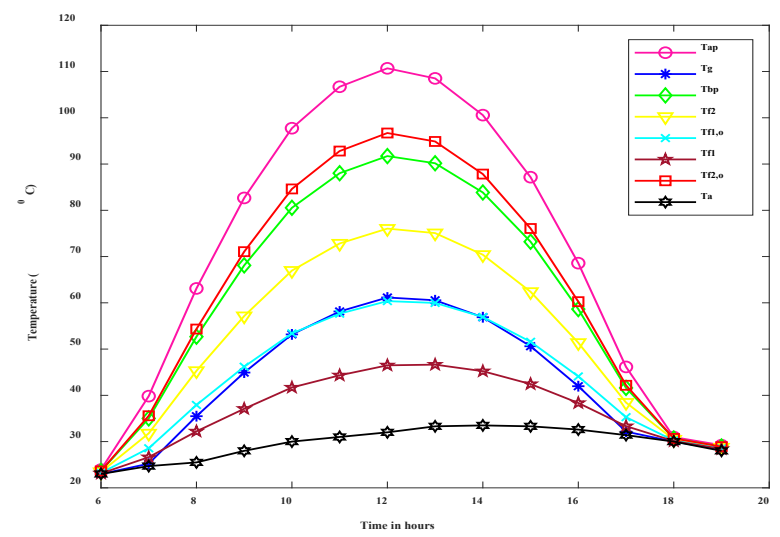

Figure 4: Hourly temperature variation at various components of the solar air heater for

$\mathrm{L}=240 \mathrm{~cm}, \mathrm{~W}_{\mathrm{c}}=120 \mathrm{~cm}, \beta=15^{0}$, and $\dot{\mathrm{m}}=$ $0.02 \mathrm{kgs}^{-1}$

The results are generated for the solar radiation intensity and ambient air temperature for the month of March for the meteorological conditions of Freetown. Fig. 4 illustrates the hourly temperatures of air in the various 
streams as well as in the different components of the solar air collector. As seen from the figure, the energy gained during the first 1 hour was utilized to heat up the collector. Fig. 4 also depicts the ambient air temperature so that the change in temperature caused by the solar air collector may be noticed. The findings in Fig. 4 can be used to describe the operating mechanism of the solar air collector. Throughtout the daylight periods inlet $T_{i}$ (ambient) air temperature enters the solar air collector first air stream and is then heated by radiation and convection energy exchange through the glazing covering to reach the stream temperature $\left(T_{f 1}\right)$. The outlet air $\left(T_{f 1,0}\right)$ from first air stream then serves as the inlet air for the second air stream which increased the second air stream temperature $\left(T_{f 2}\right)$. Consequently, $T_{f 2}$ is higher unlike $T_{f 1}$. Because the absorber plate captures direct sunlight as a black material, the temperature of the plate $\left(T_{a p}\right)$ is significantly higher throughout the day. The rise in is due to the increased temperature of the absorber surface and the increased radiative and convective heat exchanges across the plate. Consequently, beyound 19:00, there hardly any captured irradiance, hence, the temperature is relatively higher unlike the ambient temperature. Finally, the outlet air temperature $\left(T_{f 2,0}\right)$ from the second air stream then serves as the intake air for the drying chamber. Similar in curve trends of Fig. 4 can be seen in the study done by $[42,43]$. The collector's length is a crucial component to consider. It can be employed to determine the collector's expense and also to calculate the collector's return. Three collector lengths are investigated in this study to assertain their optimal outlet air temperatures at a mass flow rate of $0.02 \mathrm{~kg} / \mathrm{s}$. It was observed that increasing the collector surface leads to slight decrease in outlet air temperature as shown in Fig. 5 . The peak outlet air temperatures for collector lengths of $2.4 \mathrm{~m}, 5.4 \mathrm{~m}$, and $9.4 \mathrm{~m}$ are $91.72{ }^{\circ} \mathrm{C}, 90.67{ }^{\circ} \mathrm{C}$, and $90.39{ }^{\circ} \mathrm{C}$ respectively all occured at $12: 00$. For economical purposes, a collector length of $2.4 \mathrm{~m}$ can deliver an optimal outlet air temperature for any heating and drying application. Similar findings are related to the work done by [44].

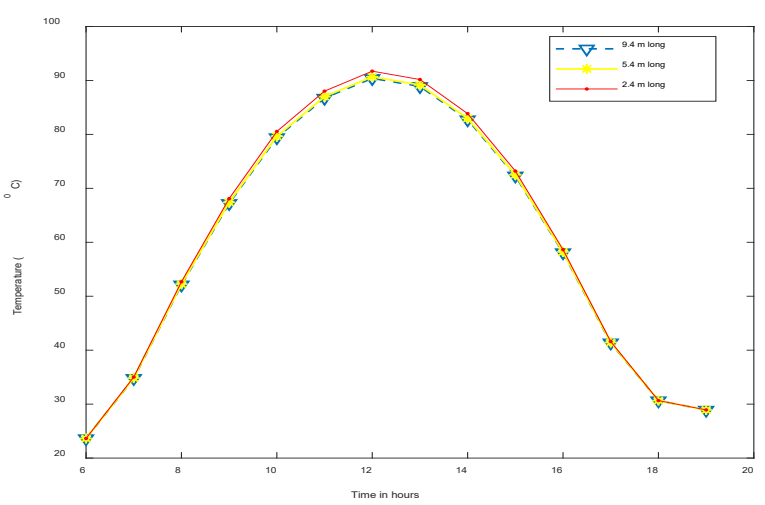

Figure 5: Effect of variation in solar air heater length on the outlet air temperatures
Fig. 6 depicts the influence of varying the mass flow rate of the flowing fluid inside the solar air heater. Undoubtly, the mass flow rate is a vital parameter in any solar air heater system. Once the ambient air mass flow rate is increased the temperature of the collector exit air decreases. The mass flow rate flowing at 0.01, 0.02, 0.03, 0.04, $0.05,0.1,0.2,0.3$, and $0.4 \mathrm{~kg} / \mathrm{s}$ can be warmed up to 118.9, 91.72, 77.30, 68.72, 63.03 , 50.14, 42.58, 39.78, and $38.30{ }^{\circ} \mathrm{C}$ respectively all occurred at midday. It is seen that, an increase in the fluid mass flow rate leads to an exponential decreased on the out put temperatures of the solar air heater. These observations are linked to the notion that the slower the air circulates, the slower it requires to be heated up. The air circulation variation at $0.01 \mathrm{~kg} / \mathrm{s}$ becomes significantly important compared to air moving at $0.4 \mathrm{~kg} / \mathrm{s}$, indicating that air circulation capacity is a crucial component. Similar curve trends can be justified to the study of [22].

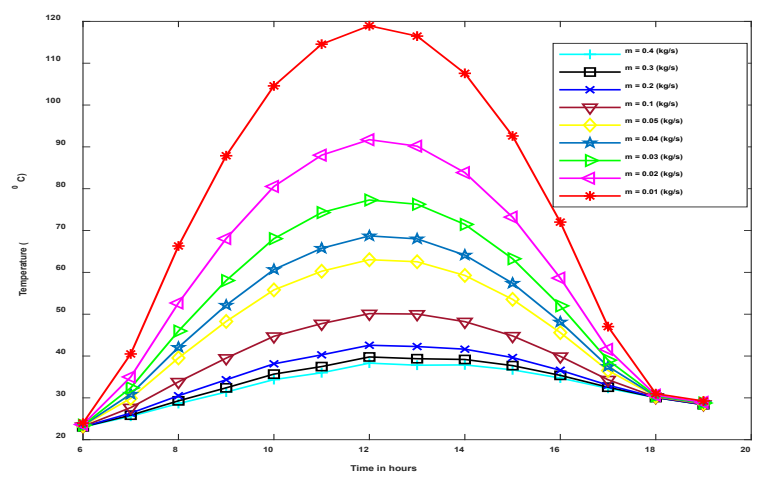

Figure 6: Influence of fluid mass flow rate within the solar collector on the air temperatures output

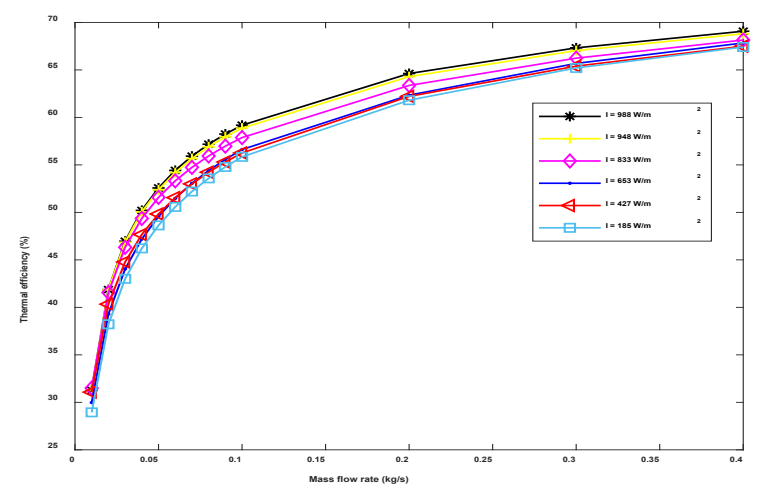

Figure 7: Influence of mass flow rate on the thermal efficiency of the solar air heater for various values of solar radiation

At different solar radiation intensities, Fig. 7 illustrates the computed results of the influence of mass flow rate on the thermal efficiency of the solar air heater. At a given solar radiation intensity value, the solar air heater thermal efficiency was observed to be significantly higher as the mass flow rates increases. The solar air heater thermal efficiency increased by approximately $30 \%$ at solar radiation of $988 \mathrm{~W} / \mathrm{m} 2$, and at mass flow rates of 0.01 to $0.4 \mathrm{~kg} / \mathrm{s}$, for this same value, the peak thermal 
efficiency of approximately $69 \%$ was observed at a mass flow rate of $0.4 \mathrm{~kg} / \mathrm{s}$. However, it is noticed that, the solar air heater thermal efficiency increases exponentially as the mass flow rate increases. This increase in the thermal efficiency is directly influenced by the solar radiation intensity. Additionally, a thermal efficiency of approximately $4 \%$ was noticed to be increased at solar radiation intensities varying from 185 to $988 \mathrm{~W} / \mathrm{m}^{2}$ at a mass flow rate of $0.4 \mathrm{~kg} / \mathrm{s}$. Consequently, as shown in Fig. 7, the thermal efficiency improves in lockstep significantly with the mass flow rate. Invariably, the mass flow rate has a significant impact on the collector's thermal efficiency. The study of [30] can justify similar results.

\section{Parametric study of the drying chamber i. Influence of drying air velocity on the drying process of onion}

The influence of drying air velocity on onion drying rate at the fifth tray is illustrated in Fig. 8. This is also investigated in terms of product moisture losses over time. When drying at a higher velocity, the drying air's ability to absorb water vapor is enhanced. Air circulating slowly around a dried product requires a significant time to fix water at a reduced rate. The evaporated vapor is effectively extracted from the product by air flowing around it. The less moist the drying air is, the higher the drying gradient from the product within the surrounding air. Our study discovered that air circulating at $5 \mathrm{~m} / \mathrm{s}$ effectively eliminates onion moisture, whereas as air flowing at 0.5 $\mathrm{m} / \mathrm{s}$ results in a prolonged drying time. As evidenced by the experimental investigation done by [45], and the simulation study done by [46], Fig. 8 reveals that air velocity is not a crucial variable as temperature, and that it impact declines as the drying process progresses.

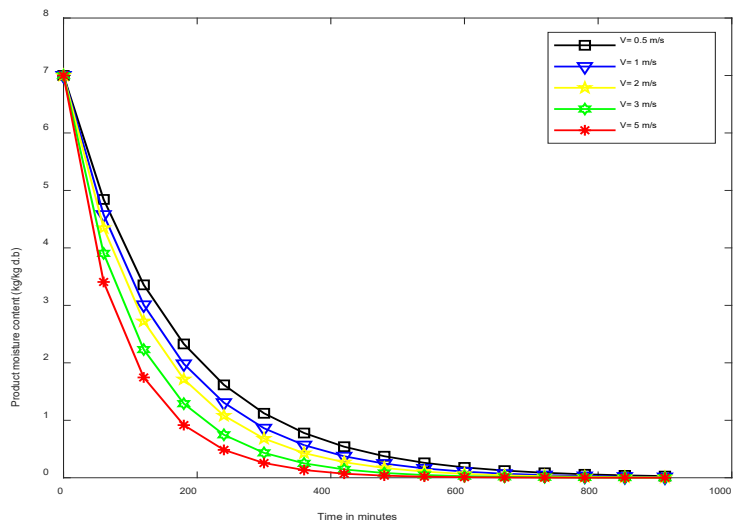

Figure 8: Variation of the air velocity on the influence of the drying process of onion $\left(5^{\text {th }}\right.$ tray, $=85^{\circ} \mathrm{C}$ and $\left.D_{f}=0.05 \mathrm{~m}\right)$

\section{Influence of the drying temperatures on the prod- uct's drying process}

The temperature is primarily and critically important component to consider in any dehydration process. Fig. 9 depicts how this variable influences moisture removal. Drying at relatively low temperatures requires a prolonged time to dry, while drying at considerably higher temperatures needs minimal time. It is important to recognize that drying at extremely high temperature may degrade the product's inherent characteristics. The impact of drying at varied steady air temperatures $\left(85^{\circ} \mathrm{C}\right.$, $65^{\circ} \mathrm{C}$, and $45^{\circ} \mathrm{C}$ ) on the drying rate is displayed in Fig. 9. Approximately 420 minutes (7 hours) was required to acquire the desired hydration at $85^{\circ} \mathrm{C}$. Even at $65{ }^{\circ} \mathrm{C}$, approximately 540 minutes ( 9 hours) seemed more than enough. Drying at $45^{\circ} \mathrm{C}$ takes slightly over 900 minutes (15 hours). It was observed that enhancing the hot air temperature results in relatively high evaporation capacity. As reported by [15], the drying period and air temperature had an inverse correlation; as the air temperature increases, the drying rate decreases.

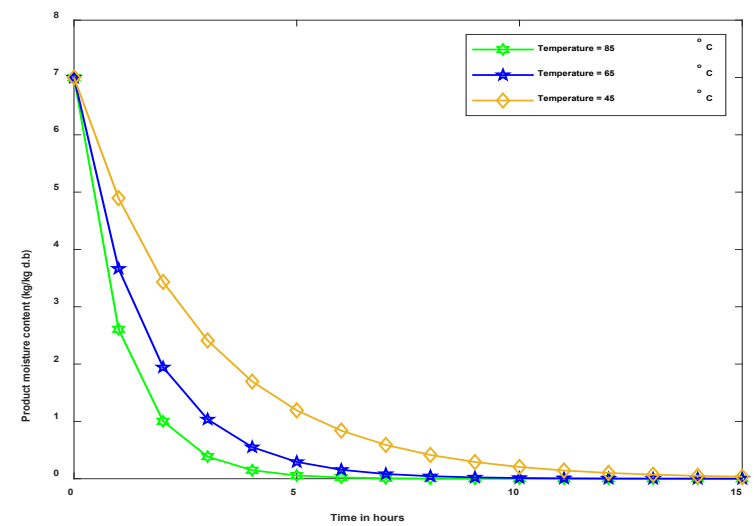

Figure 9: Influence of drying air temperature on the product's moisture content reduction

( $5^{\text {th }}$ tray, $U=2 \mathrm{~m} / \mathrm{s}, D_{f}=0.05 \mathrm{~m}, A c=2.88 \mathrm{~m}^{2}$,)

\section{Influence of tray positioning on the drying process of the onion}

The drying chamber's effectiveness is measured by the decrease in material moisture level and drying rate in various racks. Fig. 10 depicts such effect for time variation of the drying air's absolute humidity for three distinct tray levels. Apparently, the drying rate decreases between the initial and final racks. It is quite possible that this observation is due to the reality that the air temperature drops as it progresses from one rack to another. As reported by [4] in this scenario, the hot air recovers the water released by the product's evaporation. Additional cause is that the moisture emitted by the air is absorbed by the air as it progresses from the various trays, decreasing the ability of the air to absorb moisture. That is, in the final phase, the hot air regains additional lost moisture than in the previous, wherein the humidity regained by the air declines with time as there is less moisture to dissipate. 


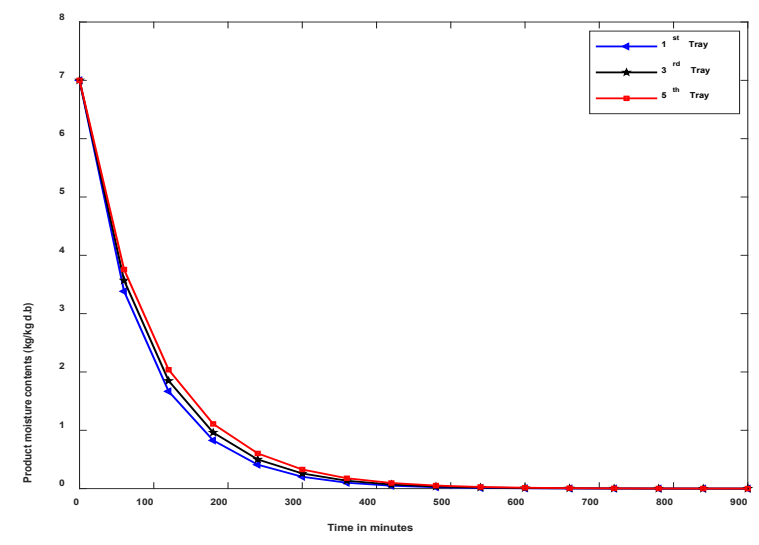

Figure 10: Influence of the drying process of the product in the first and fifth last trays

$$
\left(D_{f}=0.05 \mathrm{~m}, U=2 \mathrm{~m} / \mathrm{s}\right)
$$

\section{CONCLUSION}

Computational programs are multifunctional software that can be used in numerous studies. In the current study, we are primarily focused in the computation of a solar dryer system, and most importantly, the investigation of the drying of onion under Freetown climatic weather conditions for March 21 $1^{\text {st }}$. To achieve this, we developed equations for both the solar air heater and the drying chamber and then used them to simulate our dryer numerically. For the double-pass solar air collector, the thermal effectiveness of the double-pass solar air collector was predicted by employing a mathematical approach and resolution technique. It is made up of a steady state process approach that can concurrently compute the temperature variables for all components of the solar air heater in order to estimate the air temperature output for heat transfer variables. Furthermore, a matrix inversion technique was applied. For certain sets of operational parameters, a theoretical approach was employed to compute the thermal efficiency of the double-pass solar air heater. The variation in lengths of the solar air heater with time on the outlet air temperatures was analyzed. The influence of mass flow rate on the thermal efficiency of the system was also investigated. It was found that the thermal efficiency of the solar air heater significantly reliant on the mass flow rate. As a result, enhancing the mass flow rate across the solar air heater improves efficiency. At a mass flow rate of $0.4 \mathrm{~kg} / \mathrm{s}$ and at solar radiation intensity of $988 \mathrm{~W} / \mathrm{m} 2$, the peak thermal efficiency was found to be approximately $69 \%$. However, it was also observed that the solar air collector thermal efficiency increased by approximately $4 \%$ at solar radiation intensities varying from 185 to $988 \mathrm{~W} / \mathrm{m}^{2}$, at a mass flow rate of $0.4 \mathrm{~kg} / \mathrm{s}$. For the drying chamber, a Matlab program was developed to solve the system of equations established using the Gauss-Seidel technique. At equal moment, we carried a complete quantitative analysis of the product's kinetics and dryer effectiveness. The developed Matlab program was ideal in investigating the drying chamber's performance in a particular region. The model findings proved encouraging, and we were able to determine the variables for the different drying characteristics, resulting in the dryer's optimum effectiveness. In order to authenticate our findings for both the double-pass solar air collector and the drying chamber, our results were verified to the findings of existing investigations reported in the literature. We were able to establish that our model is viable after comparing the findings.

\section{NOMENCLATURE}

$A_{c}$ solar collector frontal area

C specific heat capacity of working fluid $(\mathrm{J} / \mathrm{kg} \mathrm{K})$

$\mathrm{C}_{\mathrm{p}}$ specific heat $(\mathrm{J} / \mathrm{kg} \mathrm{K})$

$D$ characteristic dimension $(\mathrm{m}) \mathrm{a}$

$D_{h}$ equivalence diameter $(m)$

$\mathrm{d}$ channel depth $(\mathrm{m})$

$h$, hc convective heat transfer coefficient $(\mathrm{W} / \mathrm{m} 2 \mathrm{~K})$

$\mathrm{hr}$ radiative heat transfer coefficient $(\mathrm{W} / \mathrm{m} 2 \mathrm{~K})$

I solar radiation intensity (W/m2)

j tray number

$\mathrm{k}$ thermal conductivity $(\mathrm{W} / \mathrm{m} 2 \mathrm{~K})$

$L$ collector length $(m)$

$L_{1,2,3.13}$ factor used in matrices

larg width $(\mathrm{m})$

long length $(\mathrm{m})$

$\mathrm{L}_{\mathrm{v}}$ latent heat of vaporization $(\mathrm{J} / \mathrm{kg})$

m mass flow rate $(\mathrm{kg} / \mathrm{s})$

$\mathrm{m}_{\mathrm{p}}$ mass of the chamber dryer wall $(\mathrm{kg})$

$m$ mass $(\mathrm{kg})$

Nu Nusselt number

P power absorbed $(W / m 2) \varepsilon$ emissivity

Pr Prandtl number $\mu$ viscosity

Qu heat gained by working fluid (W/m2)

Re Reynolds number

$S_{v}$ surface of one chamber dryer wall $\left(\mathrm{m}^{2}\right)$

$t$ time (s)

$\mathrm{T}$ temperature $(\mathrm{K})$

$\mathrm{U}$ velocity $(\mathrm{m} / \mathrm{s})$

$U_{b}$ bottom heat loss coefficient $\left(\mathrm{W} / \mathrm{m}^{2} \mathrm{~K}\right)$

$\mathrm{U}_{\mathrm{t}}$ top heat loss $\left(\mathrm{W} / \mathrm{m}^{2} \mathrm{~K}\right)$

$\checkmark$ wind velocity $(\mathrm{m} / \mathrm{s})$

W absolute humidity $(\mathrm{kg} / \mathrm{kg})$

$\mathrm{W}_{\mathrm{c}}$ collector width $(\mathrm{m})$

$X$ moisture content $(\mathrm{kg} / \mathrm{kg}$ dry basis)

\section{Subscripts}

$1 \& 2$ referred to first second stream

a, am ambient air

ap absorber plate 
ach heated air

b brick

bp back plate

skier vault

e external

f fluid, product

$\mathrm{g}$ glass

i inlet

o outlet, initial value

p polystyrene

$r$ radiative

s sky

w wind

\section{Greek}

a absorptivity

$\beta$ collector angle with horizontal

$\varepsilon$ emissivity

$\mu$ viscosity

$\mathrm{T}$ transmitivity

$\rho$ density $\left(\mathrm{kg} / \mathrm{m}^{3}\right)$

$\eta$ efficiency

$\sigma$ Stefan's Boltzmann constant $\left(\mathrm{W} / \mathrm{m}^{2} \mathrm{~K}\right)$

\section{REFERENCES}

1. A. El-Beltagy, G. R. Gamea, and A. H. A. Essa, "Solar drying characteristics of strawberry," J. Food Eng., vol. 78, no. 2, pp. 456-464, 2007, doi: 10.1016/j. jfoodeng.2005.10.015.

2. S. Prakash, S. K. Jha, and N. Datta, "Performance evaluation of blanched carrots dried by three different driers," J. Food Eng., vol. 62, no. 3, pp. 305-313, 2004, doi: 10.1016/S0260-8774(03)00244-9.

3. O. Prakash and A. Kumar, "Historical review and recent trends in solar drying systems," Int. J. Green Energy, vol. 10, no. 7, pp. 690-738, 2013, doi: 10.1080/15435075.2012.727113.

4. L. E. S. P. Agroalimentaires, M. Constantine, and F. Mentouri, "SIMULATION D ' UN SECHOIR SOLAIRE INDIRECT A CONVECTION FORCEE POUR k Indices et exposants ach air chaud f pe paroi extérieure $\mathrm{Cp} \mathrm{mp} \mathrm{ii} \mathrm{ie} \mathrm{n}$ e vitre extérieure isolant intérieure isolant extérieure absorbeur tranche rayonnement vitre evaporatrice voute cé," no. Décembre, pp. 57-62, 2016.

5. W. Mühlbauer, "Present status of solar crop drying," Energy Agric., vol. 5, no. 2, pp. 121-137, 1986, doi: 10.1016/0167-5826(86)90013-6.

6. S. Bala, B. K and Janjai, "Solar drying of fruits, vegetables , spices , medicinal plants and fish : Developments and Potentials," Int. Sol. Food Process. Conf. January 14- 16, 2009, Indore, India, pp. 1-24, 2009.
7. S. Misha, S. Mat, M. H. Ruslan, K. Sopian, and E. Salleh, "Review on the application of a tray dryer system for agricultural products," World Appl. Sci. J., vol. 22 , no. 3 , pp. 424-433, 2013, doi: 10.5829/idosi. wasj.2013.22.03.343.

8. A. K. Attkan, N. Kumar, and Y. K. Yadav, "Performance Evaluation of a Dehumidifier Assisted Low Temperature Based Food Drying System," IOSR J. Environ. Sci. Toxicol. Food Technol., vol. 8, no. 1, pp. 43-49, 2014, doi: 10.9790/2402-08154349.

9. W. M. Miller, "Energy storage via desiccants for food/agricultural applications," Energy Agric., vol. 2, no. C, pp. 341-354, 1983, doi: 10.1016/01675826(83)90029-3.

10. P. Catalano, F. Fucci, F. Giametta, and G. La Fianza, "A System for Food Drying Using Humidity Control and Low Temperature," Agric. Eng. Int. CIGR J., vol. X, pp. 1-10, 2008.

11. S. Misha, S. Mat, M. H. Ruslan, and K. Sopian, "Review of solid/liquid desiccant in the drying applications and its regeneration methods," Renew. Sustain. Energy Rev., vol. 16, no. 7, pp. 4686-4707, 2012, doi: 10.1016/j.rser.2012.04.041.

12. C. L. Hii, C. L. Law, and M. Cloke, "3116-3120.Pdf," Determination of Effective Diffusivity of Cocoa Beans using Variable Diffusivity Model, vol. Journal of. pp. 3116-3120, 2009.

13. A. Matouk, M. El-Kholy, M. El-Sadany, and A. Abd - El-aziz, "Development and Evaluation of a Solar Dryer for Thin Layer Drying of Hayani Date," J. Soil Sci. Agric. Eng., vol. 1, no. 6, pp. 517-532, 2010, doi: 10.21608/jssae.2010.74880.

14. M. A. Hossain, J. L. Woods, and B. K. Bala, "Simulation of solar drying of chilli in solar tunnel drier," Int. J. Sustain. Energy, vol. 24, no. 3, pp. 143-153, 2005, doi: 10.1080/14786450500291859.

15. E. K. Akpinar, Y. Bicer, and C. Yildiz, "Thin layer drying of red pepper," J. Food Eng., vol. 59, no. 1, pp. 99-104, 2003, doi: 10.1016/S0260-8774(02)004259.

16. P. D. Uwitije, R. Hantoro, M. Y. Nasri, and G. Nugroho, "Study and Simulation of A Solar System for Drying Purpose in Rwanda," IOP Conf. Ser. Mater. Sci. Eng., vol. 462, no. 1, 2019, doi: 10.1088/1757899X/462/1/012001.

17. Y. B. Chauhan and P. P. Rathod, "A comprehensive review of the solar dryer," Int. J. Ambient Energy, vol. 41, no. 3, pp. 348-367, 2020, doi: 10.1080/01430750.2018.1456960.

18. O. Prakash, V. Laguri, A. Pandey, A. Kumar, and A. Kumar, "Review on various modelling techniques for the solar dryers," Renew. Sustain. Energy Rev., vol. 62, pp. 396-417, 2016, doi: 10.1016/j. rser.2016.04.028. 
19. L. M. Diamante and P. A. Munro, "Mathematical modelling of the thin layer solar drying of sweet potato slices," Sol. Energy, vol. 51, no. 4, pp. 271-276, 1993, doi: 10.1016/0038-092X(93)90122-5.

20. C. Ratti and A. S. Mujumdar, "Solar drying of foods: Modeling and numerical simulation," Sol. Energy, vol. 60, no. 3-4, pp. 151-157, 1997, doi: 10.1016/ S0038-092X(97)00002-9.

21. L. Bennamoun, "Reviewing the experience of solar drying in Algeria with presentation of the different design aspects of solar dryers," Renew. Sustain. Energy Rev., vol. 15, no. 7, pp. 3371-3379, 2011, doi: 10.1016/j.rser.2011.04.027.

22. S. Aboul-Enein, A. A. El-Sebaii, M. R. I. Ramadan, and H. G. El-Gohary, "Parametric study of a solar air heater with and without thermal storage for solar drying applications," Renew. Energy, vol. 21, no. 3-4, pp. 505-522, 2000, doi: 10.1016/S09601481(00)00092-6.

23. D. Jain, "Modeling the system performance of multitray crop drying using an inclined multi-pass solar air heater with in-built thermal storage," J. Food Eng., vol. 71 , no. 1 , pp. 44-54, 2005, doi: 10.1016/j.jfoodeng.2004.10.016.

24. D. Jain and R. K. Jain, "Performance evaluation of an inclined multi-pass solar air heater with in-built thermal storage on deep-bed drying application," J. Food Eng., vol. 65, no. 4, pp. 497-509, 2004, doi: 10.1016/j.jfoodeng.2004.02.013.

25. O. V. Ekechukwu and B. Norton, "Review of solar-energy drying systems II: An overview of solar drying technology," Energy Convers. Manag., vol. 40, no. 6, pp. 615-655, 1999, doi: 10.1016/S01968904(98)00093-4.

26. D. Jain, "Modeling the performance of the reversed absorber with packed bed thermal storage natural convection solar crop dryer," J. Food Eng., vol. 78, no. 2, pp. 637-647, 2007, doi: 10.1016/j.jfoodeng.2005.10.035.

27. S. Timoumi, D. Mihoubi, and F. Zagrouba, "Simulation model for a solar drying process," Desalination, vol. 168, no. 1-3, pp. 111-115, 2004, doi: 10.1016/j. desal.2004.06.175.

28. O. P. Dubey and T. L. Pryor, "A user oriented simulation model for deep bed solar drying of rough rice," Renew. Energy, vol. 9, no. 1-4 SPEC. ISS., pp. 695699, 1996, doi: 10.1016/0960-1481(96)88380-7.

29. A. Fudholi, K. Sopian, M. H. Ruslan, and M. Y. Othman, "Performance and cost benefits analysis of double-pass solar collector with and without fins," Energy Convers. Manag., vol. 76, pp. 8-19, 2013, doi: 10.1016/j.enconman.2013.07.015.
30. A. Fudholi, M. H. Ruslan, and M. Y. Othman, "Mathematical Model of Double-Pass Solar Air Collector," Latest Trends Renew. Energy Environ. Informatics. Proc. 7th Int. Conf. Renew. Energy Sources, pp. 279-283, 2013.

31. M. Fakoor Pakdaman, A. Lashkari, H. Basirat Tabrizi, and R. Hosseini, "Performance evaluation of a natural-convection solar air-heater with a rectangular-finned absorber plate," Energy Convers. Manag., vol. 52, no. 2, pp. 1215-1225, 2011, doi: 10.1016/j. enconman.2010.09.017

32. K. S. Ong, "Thermal performance of solar air heaters: Mathematical model and solution procedure," Sol. Energy, vol. 55, no. 2, pp. 93-109, 1995, doi: 10.1016/0038-092X(95)00021-I.

33. E. M. Ali Alfegi, K. Sopian, M. Y. H. Othman, and B. Bin Yatim, "Mathematical model of double pass photovoltaic thermal air collector with fins," Am. J. Environ. Sci., vol. 5, no. 5, pp. 592-598, 2009, doi: 10.3844/ajessp.2009.592.598.

34. C. T. Kiranoudis, Z. B. Maroulis, and D. Marinos-Kouris, "Drying kinetics of onion and green pepper," Dry. Technol., vol. 10, no. 4, pp. 995-1011, 1992, doi: 10.1080/07373939208916492.

35. C. T. Kiranoudis, J. Dimitratos, Z. B. Maroulis, and D. Marinos-Kouris, "State Estimation in the Batch DryinG of Foods," Dry. Technol., vol. 11, no. 5, pp. 10531069, 1993, doi: 10.1080/07373939308916882.

36. C. T. Kiranoudis, Z. B. Maroulis, and D. Marinos-Kouris, "Model selection in air drying of foods," Dry. Technol., vol. 10, no. 4, pp. 1097-1106, 1992, doi: 10.1080/07373939208916497.

37. M. K. Krokida, V. T. Karathanos, Z. B. Maroulis, and D. Marinos-Kouris, "Drying kinetics of some vegetables," J. Food Eng., vol. 59, no. 4, pp. 391-403, 2003, doi: 10.1016/S0260-8774(02)00498-3.

38. C. T. Kiranoudis, Z. B. Maroulis, E. Tsami, and D. Marinos-Kouris, "Equilibrium moisture content and heat of desorption of some vegetables," J. Food Eng., vol. 20 , no. 1 , pp. 55-74, 1993, doi: 10.1016/02608774(93)90019-G.

39. A. Samara, S. De Oliveira, and Z. Ernesto, "NUMERICAL SIMULATION OF A HYBRID SOLAR DRYER FOR," 1985.

40. L. Bennamoun and A. Belhamri, "Design and simulation of a solar dryer for agriculture products," J. Food Eng., vol. 59, no. 2-3, pp. 259-266, 2003, doi: 10.1016/S0260-8774(02)00466-1.

41. D. Y. Goswami, Principles of Solar Engineering. 2015.

42. M. A. Karim, E. Perez, and Z. M. Amin, "Mathematical modelling of counter flow v-grove solar air collector," Renew. Energy, vol. 67, pp. 192-201, 2014, doi: 10.1016/j.renene.2013.11.027. 
43. P. Pascal, U. Canissius, B. Germain, T. Alphonse, and P. E. Alidina, "Study and Modelisation the Parameters of Plate Solar air Collector at Single Pass for Drying of Madagascar CocoaBeans," no. 8, pp. 8-14, 2017.

44. L. Bennamoun and A. Belhamri, "Study of solar thermal energy in the north region of Algeria with simulation and modeling of an indirect convective solar drying system," Nat. \&Technology, vol. 4, no. December 2013, pp. 34-40, 2011.
45. I. T. Toğrul and D. Pehlivan, "Modelling of drying kinetics of single apricot," J. Food Eng., vol. 58, no. 1, pp. 23-32, 2003, doi: 10.1016/S0260-8774(02)00329-1.

46. L. Bennamoun and A. Belhamri, "Numerical simulation of drying under variable external conditions: Application to solar drying of seedless grapes," J. Food Eng., vol. 76, no. 2, pp. 179-187, 2006, doi: 10.1016/j.jfoodeng.2005.05.005. 